\title{
ANALISIS STRUKTUR DAN FUNGSI BAHASA SUKU HUBULA LEMBAH BALIM PAPUA DALAM PERKEMBANGAN ERA MODEREN ANALYSIS OF THE STRUCTURE AND FUNCTION OF HUBULA LAN- GUAGE FROM BALIM VALLEY PAPUA IN THE DEVELOPMENT OF MODERN ERA
}

Naskah masuk: 1 Februari 2021, direview: 1 Februari 2021, disetujui: 6 April 2021

\author{
Grets Lewis Theodore Walilo \\ FKIP Universitas Cenderawasih \\ Ponsel: 081218063872
}

\begin{abstract}
The purpose of this study is to understand the structure and function of Hubula tribe language from Balim Valley Papua with its development in the modern era. Whereas, the language has an easy sentence pattern to be identified. This research was conducted with a sociolinguistic approach that focused on the usage of language in the society to perform its function. The result showed that Hubula tribe language is still favorable in Balim Valley even at the modern era. By knowing some basic vocabularies, the sentence's structure of Hubula tribe language can be identified easily. As the bridge for interaction, this language has several functions such as; personal function, informative function, interaction function and regulatory function.
\end{abstract}

Keywords: Hubula tribe language, language's structure, language's function, modern era

\begin{abstract}
ABSTRAK
Penelitian ini bertujuan untuk memahami struktur dan fungsi dari bahasa Hubula di lembah Balim Papua dengan perkembangannya dalam era modern. Bahasa ini memiliki pola kalimat yang mudah untuk diidentifikasi. Penelitian ini dilakukan dengan pendekatan sosiolinguistik yang berfokus pada pemakaian bahasa dalam masyarakat untuk menjalankan fungsi-fungsi yang terkandung. Hasilnya ditemukan bahwa bahasa Hubula masih diminati di Lembah Balim bahkan dalam era modern. Dengan menguasai beberapa kata-kata dasar, struktur dari pada kalimat Bahasa Hubula dapat diidentifikasi dengan mudah. Sebagai jembatan untuk berinteraksi, bahasa ini memiliki beberapa fungsi seperti fungsi personal, fungsi informatif, fungsi interaksional, dan fungsi regulatoris.
\end{abstract}

Kata kunci: bahasa Hubula, struktur bahasa, fungsi bahasa, era modern

\section{PENDAHULUAN}

Papua merupakan daerah yang berlimpah baik dari segi kekayaan alam maupun budaya. Beragam budaya yang adapun membuat Papua memiliki bahasa-bahasa daerah yang beragam. Bahasa daerah adalah identitas yang dimiliki oleh setiap orang yang berasal dari suku tertentu. Dimana, bahasa-bahasa yang ada telah diwariskan secara turun-temurun hingga kini. Bahasa daerah adalah media pengantar yang membantu proses komunikasi antara satu orang dengan orang lain nya dalam suatu suku tertentu (Itlay, 1994). Sebagai suatu pengantar, bahasa tentu menjadi aspek yang sangat berarti dalam kehidupan seseorang. Dengan adanya bahasa, semua dapat dimengerti dan berjalan dengan baik.

Secara geografis, Papua dapat dibagi menjadi tujuh bagian berdasarkan wilayah adat. Adapun ketujuh wilayah adat tersebut antara lain Mamta, Saireri, Bomberai, Domberai, Ha-anim, La-pago, dan Mi-pago (dalam Samakori, 2008). Dalam data literal, 
ketujuh wilayah adat yang ada mewakili dua ratus empat puluh delapan suku yang ada di Papua.

Lembah Balim terletak di pegunungan tengah Jayawijaya. Ada lima suku besar yang mendiami daerah tersebut, salah satunya adalah suku Hubula sebagai penutur bahasa Hubula dan menjadi objek penelitian ini. Bahasa suku Hubula hingga kini memiliki penutur pada kisaran di bawah 100000 penutur (Wetipo, 2018). Namun, setiap suku dan subsuku Hubula memiliki dialek yang berbeda. Dalam perkembangan zaman, dikhawatirkan bahasa Hubula mulai ditinggalkan atau mengalami pergeseran.

Perkembangan zaman dan perpindahan penduduk membuat terjadinya kontak budaya. Budaya-budaya baru mulai memasuki Lembah Balim dan memengaruhi baik budaya maupun bahasa setempat. Akulturasi menjadi satu pokok permasalahan yang cukup besar. Perubahan yang ada membuat bahasa dan budaya asli mulai tertindih oleh kebudayaan baru yang lebih diminati oleh khalayak umum. Bahasa suku Hubula mengalami perubahan dalam perkembangan zaman. Adapun perubahan yang terjadi tidak makro. Perubahan utama ada pada struktur kalimat. Selanjutnya, ada beberapa kosakata yang tidak dimiliki oleh suku Hubula, telah dimiliki sekarang melalui proses penyerapan bahasa.

Beberapa peneliti bahasa dan ahli kebudayaan sebelumnya telah melakukan penelitian terkait dengan struktur dan fungsi bahasa Hubula. Penelitian tersebut termuat dalam buku yang ditulis oleh Simeon Itlay (1994) yang melakukan kajian akan struktur dan pola bahasa suku Hubula. Wetipo (2018) dan Grets Walilo (2019) juga membahas fungsi dari bahasa Hubula dan contoh pemakaiannya. Rujukan dari penulis asing berasal dari Peter Matthiessen (1987). Matthiessen meneliti kebudayaan dan bahasa penduduk Kurulu di Lembah Balim. Kajian-kajian seperti tersebut di atas sangatlah penting dalam proses analisis bahasa Hubula sebagai sumber referensi dan bahan pembelajaran. Penelitian ini hendak melanjutkan kajian yang telah ada untuk bahasa Hubula dengan pendekatan yang berbeda, yaitu fungsi bahasa dalam masyarakat Papua, khususnya bahasa Hubula dalam mengikuti perkembangan zaman di Lembah Balim.

Bahasa Hubula seperti halnya bahasa daerah lainnya, terbentuk dari interaksi antara manusia dan alam. Setiap suku kata yang terbentuk adalah hasil dari proses pengamatan dan interaksi manusia dengan lingkungan sekitarnya. Dengan demikian, bahasa Hubula memiliki perbendaharaan suku kata yang cukup mudah dan sederhana karena bahasa tercipta hanya dari lingkungan sekitar. Namun dalam era modern, bahasa Hubula mulai menyerap kosakata bahasa Indonesia yang memengaruhi bahasa Hubula tersebut.

Bahasa Hubula memiliki penutur terbanyak di pegunungan tengah Papua membuat bahasa ini layak untuk dikaji lebih lanjut. Adapun teori yang digunakan adalah teori sosiolinguistik, khususnya melalui pendekatan pluralisme yang berdasarkan pada fungsi-fungsi bahasa. Menurut Wardhough (1992), sosiolinguistik berfokus kepada pencarian hubungan antara bahasa dan masyarakat dengan tujuan utama memahami struktur sebuah bahasa dan bagaimana fungsi bahasa dalam komunikasi. Bahasa secara umum memiliki banyak fungsi. Bahasa daerah maupun bahasa negara memiliki fungsi yang sama pada dasarnya. Berdasarkan pendekatan pluralisme pada fungsi-fungsi bahasa, ada tujuh fungsi bahasa menurut Halliday (via Tarigan, 1986), yaitu fungsi instrumental, fungsi regulasi, fungsi interaksi, fungsi personal, fungsi heuristik, fungsi imajinatif, dan fungsi informatif. Dari tujuh fungsi bahasa yang ada, ada empat fungsi bahasa yang akan menjadi fokus utama dari penelitian ini. Fungsi-fungsi tersebut adalah fungsi personal, informatif, interaksional, dan regulatoris. Dengan menggunakan teori sosiolinguistik dan pendekatan pluralisme yang mengambil fokus pada fungsi bahasa, 
penelitian ini akan menganalisis fungsi bahasa Hubula di era modern.

\section{METODE PENELITIAN}

Penelitian ini adalah penelitian deskriptif kualitatif. Data-data yang ada merupakan data sekunder. Sumber utama data-data tersebut adalah buku-buku literasi kebudayaan lembah Balim dan hasil wawancara bersama salah satu tokoh masyarakat Hubula dari Wamena, Pendeta Esmon Walilo, M.Th. Data-data yang terkumpul kemudian ditranskripsi dan diklasifikasi. Selanjutnya, kajian fungsi bahasa dalam penelitian ini dilakukan dengan melihat unsur makna yang terdapat dalam suatu kalimat juga strukturnya. Adapun perbendaharaan kosakata baru merupakan hasil dari serapan dan akan dijelaskan secara terperinci. Fungsi bahasa secara verbal dan tertulis diamati dalam kehidupan sehari-hari masyarakat penuturnya.

\section{HASIL DAN PEMBAHASAN}

Bahasa sebagai alat komunikasi memegang peranan penting dalam suatu masyarakat. Menurut Wibowo (2001:3), bahasa adalah sistem simbol bunyi yang bermakna dan berartikulasi (dihasilkan oleh alat ucap) yang bersifat arbitrer dan konvensional, yang dipakai sebagai alat berkomunikasi oleh sekelompok manusia untuk melahirkan perasaan dan pikiran. Dengan demikian, bahasa tentu dapat membantu manusia dalam kehidupan sehari-hari.

Bahasa daerah, secara khusus dan literal merupakan warisan budaya dari satu generasi ke generasi selanjutnya yang memegang fungsi penting dalam suatu kelompok masyarakat dalam kebudayaan tertentu. Bahasa Hubula memiliki struktur yang sederhana dan perbendaharaan kata yang banyak. Struktur dan perbendaharaan kata mulai berubah dalam konteks mikro dalam era moderen, sedangkan fungsi-fungsi yang ada tetaplah sama. Ada empat dari tujuh fungsi bahasa Hubula yang akan dibahas dalam bagian ini.

\subsection{Struktur Pola Kalimat}

Bahasa Indonesia memiliki pola SPOK, sedangkan struktur bahasa suku Hubula memiliki pola kalimat yang tidak teratur. Ada sekitar 24 pola kalimat yang tidak teratur secara keseluruhan. Struktur bahasa Hubula dapat berupa SPO, SOP, PSO, SPKO, dan KSPO.

Dari total pola kalimat yang ada, satu pola telah menjadi pola umum yang paling mudah untuk dipahami, baik penutur bahasa Hubula maupun penutur asing, yang mempelajari bahasa Hubula. Pola tersebut dapat diamati sebagai berikut.

\section{Subjek + Objek + Predikat}

Berbeda dengan bahasa Indonesia yang memiliki keterangan, bahasa Hubula terkadang tidak memiliki keterangan di akhir kalimat. Pola kalimat yang ada pada umumnya menjelaskan dan menyampaikan pesan kepada lawan bicara. Hal ini dapat dilihat melalui tabel berikut.

\begin{tabular}{|c|c|}
\hline Bahasa Indonesia & Bahasa Hubula \\
\hline Saya pergi ke Jayapura & An Jayapura Lan \\
\hline
\end{tabular}

Pada bahasa Hubula, objek ditempatkan lebih dulu setelah subjek kemudian predikat. Hal ini sangatlah berbeda dengan bahasa Indonesia maupun bahasa Inggris yang menempatkan predikat setelah subjek. Untuk predikat/kata kerja (verba), ada dua jenis verba, yaitu verba terikat dan verba bebas. Verba terikat merupakan verba yang 
memiliki pasangan khusus subjek tertentu. Verba bebas adalah verba yang dapat berdiri dengan semua subjek tanpa adanya batasan. Berikut adalah jenis-jenis verba yang dirangkum dalam table.

Verba Terikat

\begin{tabular}{|c|c|c|c|c|}
\hline Verba & Wilayah & \multicolumn{3}{|c|}{ Waktu } \\
\cline { 3 - 5 } & & Sedang & Akan & Telah Selesai \\
\cline { 3 - 5 } & & & Lak/Legein/Lan & Lagerik \\
\hline Pergi & B (Wamena) & Lagolagi & & \\
\hline
\end{tabular}

Dengan demikian, verba-verba di atas hanya dapat berpasangan dengan subjek tertentu yang merupakan pasangannya. Contoh:

$$
\begin{array}{ll}
\text { An Jakarta lak } & \text { : saya akan pergi ke Jakarta } \\
\text { Hit Jakarta lan } & \text { : kalian akan pergi ke Jakarta }
\end{array}
$$

Verba Lak hanya dapat berpasangan dengan orang pertama tunggal an (saya). Sedangkan verba lan hanya boleh dipakai untuk subjek bit (anda), orang ketiga tunggal. Pola kalimat yang digunakan adalah SOP (subjeknya ialah an dan bit, objeknya Jakarta dan predikatnya ialah lak atau lan).

\section{Verba Bebas}

\begin{tabular}{|c|c|c|l|}
\hline Verba & Wilayah & BSH & Subjek \\
\hline Bawa & B (Wamena) & Wolok & $\begin{array}{l}\text { An (saya), Hit (kalian), Nit (kami), Hat } \\
\text { (kamu) It (mereka), At (dia) }\end{array}$ \\
\hline
\end{tabular}

Verba ini dapat dipakai untuk semua subjek, tanpa ada aturan khusus yang mengikat. Contohnya kalimat berikut.

- An kue wolok : saya bawa kue

- It kue wolok : mereka bawa kue

- At kue wolok : dia bawa kue

Tidak ada perubahan bentuk verba layaknya verba terikat. Verba wolok tetap sama di segala jenis subjek. Pola kalimat yang digunakan adalah sama, yaitu SOP (Subjek nya ialah an, it, dan at. Objeknya adalah kue dan predikatnya ialah wolok). Dalam praktiknya, walaupun ada banyak pola kalimat dalam BSH, tapi pola kalimat yang paling sering digunakan dan yang paling mudah ialah SOP.

Dalam perkembangan zaman, pola kalimat yang digunakan dan paten adalah pola kalimat umum yang telah dijelaskan sebelumnya. Dalam bahasa Hubula, ada beberapa kata-kata yang tidak ada. Kosakata yang tidak ada dalam perbendaharaan bahasa ini kemudian diserap dari bahasa Indonesia. Berikut adalah perwakilan serapan kata bahasa Indonesia kedalam bahasa Hubula.

\section{Kata-kata Serapan}

\begin{tabular}{|c|l|l|}
\hline $\begin{array}{c}\text { No } \\
\cdot\end{array}$ & \multicolumn{1}{|c|}{$\begin{array}{c}\text { Bahasa } \\
\text { Serapan }\end{array}$} & \multicolumn{1}{c|}{ Penjelasan } \\
\hline 1 & Kue & $\begin{array}{l}\text { Bahasa Hubula hanya memiliki bipere untuk mewakili } \\
\text { nasi dan ubi }\end{array}$ \\
\hline 2 & $\begin{array}{l}\text { Kendaraan } \\
\text { (Mobil, Motor, } \\
\text { Pesawat })\end{array}$ & $\begin{array}{l}\text { Kosakata ini diserap langsung karena pada zama dahulu, } \\
\text { belum terdapat jenis transportasi sehingga penyerapan } \\
\text { dan penggunaan langsung bahasa Indonesia dilakukan. }\end{array}$ \\
\hline
\end{tabular}




\begin{tabular}{|c|c|c|}
\hline 3 & Komputer & Komputer juga diserap dan digunakan secara langsung. \\
\hline 4 & $\begin{array}{l}\text { Telepon } \\
\text { genggam (gawai) }\end{array}$ & $\begin{array}{l}\text { Dalam praktiknya, 'gawai' merupakan pun atau kata } \\
\text { dengan makna ganda. Bahasa Hubula, gawai ialah } \\
\text { mulut. Namun, gawai sebagai sarana komunikasi pun } \\
\text { diserap sebagai terminologi baru. }\end{array}$ \\
\hline 5 & $\begin{array}{l}\text { Sandang } \\
\text { sepatu, } \\
\text { rok) }\end{array}$ & $\begin{array}{l}\text { Bahasa Hubula hanya mengenal baju karena pada saat } \\
\text { awal adanya bahasa, beberapa jenis sandang lain } \\
\text { tidaklah tersedia. }\end{array}$ \\
\hline 6 & Numeralia & $\begin{array}{l}\text { Bahasa Hubula hanya memiliki angka satu hingga lima } \\
\text { sehingga angka enam dan seterusnya menggunakan } \\
\text { bahasa Indonesia. }\end{array}$ \\
\hline 7 & Kacamata & Kaca mata juga diserap dan digunakan secara langsung. \\
\hline 8 & Pena Buku & $\begin{array}{l}\text { Bahasa Hubula hanya mengenal buku karena pada awal } \\
\text { adanya bahasa, beberapa sandang lain tidaklah tersedia. }\end{array}$ \\
\hline 9 & $\begin{array}{l}\text { Peralatan mandi } \\
\text { (sabun, sampo) }\end{array}$ & $\begin{array}{l}\text { Pada zaman dahulu, penduduk suku ini membersihkan } \\
\text { tubuh mereka di kali terdekat sehingga belum mengenal } \\
\text { peralatan mandi. }\end{array}$ \\
\hline 10 & $\begin{array}{l}\text { Peralatan makan } \\
\text { (Piring, Sendok, } \\
\text { Garpu) }\end{array}$ & $\begin{array}{l}\text { Makanan pokok suku Hubula adalah ubi. Dengan } \\
\text { demikian, peralatan makan tidak dikenal pada masa } \\
\text { lampau. }\end{array}$ \\
\hline 11 & $\begin{array}{l}\text { Peralatan } \\
\text { elektronik lain } \\
\text { nya (Kamera, } \\
\text { televisi, tablet) }\end{array}$ & $\begin{array}{l}\text { Peralatan elektronik merupakan kata-kata yang langsung } \\
\text { diserap dan digunakan dalam bahasa Hubula. }\end{array}$ \\
\hline 12 & Koper & $\begin{array}{l}\text { Koper merupakan sesuatu yang baru sehingga tidak ada } \\
\text { dalam kosakata bahasa Hubula. }\end{array}$ \\
\hline 13 & Listrik & $\begin{array}{l}\text { Pada saat bahasa Hubula mulai ada, belum ada listrik } \\
\text { sehingga listrik perlu diserap ke dalam bahasa ini. }\end{array}$ \\
\hline 14 & Kompor & $\begin{array}{l}\text { Masyarakat suku Hubula menggunakan tungku } \\
\text { tradisional sehingga kompor adalah kosakata yang baru } \\
\text { bagi mereka. }\end{array}$ \\
\hline
\end{tabular}

Beberapa kosakata di atas merupakan kata-kata dari bahasa Indonesia yang langsung diserap ke dalam bahasa Hubula. Dalam perkembangan zaman, bahasa Hubula yang masih digunakan, harus dapat bertahan dengan adanya kosakata baru. Dengan demikian, bahasa Hubula tetap berkembang dan digunakan, walaupun dengan cara menyerap bahasa Indonesia sebagai bahasa negara.

\subsection{Fungsi Personal}

Fungsi ini adalah fungsi bahasa yang menyatakan beberapa hal yang terkait langsung dengan penuturnya. Fungsi personal mencerminkan langsung karakter dan kepribadian dari penuturnya. Dalam melakukan percakapan, fungsi ini dapat memberi lawan bicara, gambaran umum tentang kepada siapa mereka sedang berbicara. Adapun fungsi personal dapat dibagi menjadi tiga berdasarkan penggunaannya untuk mengungkapkan hal berikut.

\section{a. Perasaan}

Perasaan yang diungkapkan dapat beragam dan mencangkup semua jenis 
perasaan, tergantung konteks pemakaian nya. Berikut beberapa contohnya.

1) An kue nele

Saya lapar kue

2) Motor hano motok nagosa, waa

Motornya bagus sekali mama, terima kasih

3) Mobil weako

Mobilnya jelek

Ketiga contoh di atas adalah contoh kalimat-kalimat sederhana yang mencerminkan perasaan dalam kehidupan sehari-hari. Contoh 1) menyatakan perasaan lapar, sedangkan contoh-contoh selanjutnya menyatakan kepuasan dan ketidakpuasan pada sesuatu seperti contoh 2) dan 3). Kalimat bahasa Hubula sangat sederhana dan langsung menyatakan pesan utamanya.

b. Pendapat

Pendapat merupakan salah satu bagian terpenting yang akan menjadi refleksi dari penuturnya. Pada bagian ini, berikut contohnya.

1) Pesawat iti earak

Pesawat itu kecil

2) An nakla komputer hano apigi

Saya rasa komputernya bagus

Kedua contoh di atas merupakan contoh pendapat seseorang terhadap sesuatu. Dalam hal ini, contoh 1) menyatakan bahwa pesawat memiliki ukuran yang relatif tidak besar, sedangkan contoh 2) menyatakan pandangan pribadi penutur kepada suatu objek, dalam hal ini komputer yang dinilai bagus.

c. Sikap

Pada bagian ini, penutur bahasa menyatakan sikap yang akan diambil terhadap suatu pokok pembahasan. Berikut contoh kalimatnya.

1) Antopinait

Saya tidak suka topi nya.

2) NithialekJakartalago

Kita akan ke Jakarta besok.

Pada kedua contoh di atas, penutur dengan jelas menyatakan sikapnya terhadap sesuatu. Pada contoh 1) penutur menyatakan sikap penolakan dengan mengkritik topi yang ada. Selanjutnya, pada contoh 2) penutur menyatakan siap dan tindakan yang akan diambilnya; pergi ke Jakarta. Dari fungsi personal, ada tiga subbagian yang menyusun satu fungsi yang besar secara satu kesatuan. Perasaan, pendapat, maupun sikap dapat dinyatakan melalui bahasa Hubula.

\subsection{Fungsi Informatif}

Pada fungsi ini, bahasa digunakan sebagai suatu media untuk menyatakan atau memberikan informasi. Informasi yang diberikan adalah beragam. Informasi dapat berupa ilmu pengetahuan, budaya, ataupun hanya sekedar kabar saja. Fungsi ini dapat dilihat dalam contoh-contoh berikut.

1) Hp kok eti hano

Hp besar itu bagus

2) Sepatu eti Jakarta meke

Sepatu itu datang dari Jakarta

3) Sabun eti kume hasik

Sabun itu untuk mandi

4) Kompor eti isasusak basik

Kompor itu untuk masak nasi 


\section{5) Sendok eti nasak hasik \\ Sendok itu untuk makan}

Setiap contoh-contoh diatas memberikan informasi yang berbeda-beda. Pada contoh 1) memberikan informasi mengenai telepon genggam, contoh 2) memberikan informasi tentang asal usul suatu objek, dan contoh 3) mengarah kepada kegunaan dari pada suatu objek. Informasi yang diberikan berbeda-beda, tetapi tujuan utamanya adalah menyampaikan suatu informasi.

\subsection{Fungsi Interaksional}

Pada fungsi ini, bahasa digunakan sebagai media untuk berbicara, berhubungan dan berinteraksi antara penutur dan lawan bicara. Fungsi ini memudahkan setiap orang yang terlibat dalam percakapan untuk saling berinteraksi dan mempermudah transaksi, percakapan serta aktivitas lainnya. Adapun contoh-contoh dalam bahasa Hubula sebagai berikut.

1) An pena oko palikiluk

Saya mau beli pena

2) An sampo Jayapura wani lagaluk.

Saya beli sampo di Jayapura

3) Koper yi oko meren?

Berapa harga koper ini?

4) Kaca mata yi usike

Kacamata itu jatuh

5) Hat piring koma okopale?

Dimana kamu beli piring?

Ada lima contoh di atas yang semuanya membantu penutur dan lawan bicara saat dalam proses percakapan. Pada contoh 1), kalimat yang digunakan dalam interaksi antara pelanggan dan penjual dalm situasi transaksi, contoh 2) menyatakan asal usul suatu objek yang akan kemudia mendapatkan tanggapan dari para lawan bicara dalam interaksi percakapan, contoh 3) adalah situasi transaksional antara pembeli dan pedagang, pembeli bertanya tentang harga koper, contoh 4) memberi tahu bahwa kacamata telah jatuh sehingga dalam interaksi tersebut akan ada aksi yang diambil, dan contoh 5) merupakan contoh interaksi yang menunjukan rasa ingin tahu atau penasaran. Kelima contoh d iatas dengan jelas menunjukan bahasa Hubula dapat digunakan bukan hanya untuk berkomunikasi, tetapi sebagai sarana untuk berinteraksi.

\subsection{Fungsi Regulatoris}

Fungsi regulatoris adalah fungsi bahasa yang secara spesifik digunakan untuk mengatur perilaku seseorang dalam percakapan ataupun dalam konteks kehidupan sehari-hari. Berikut beberapa contohnya.

1) Eloma lawun

Jangan pergi ke sana

2) Kab hagatun

Jangan nakal

3) Eloma nan

makan di sana

4) Eloma lan

Pergi ke sana

Yoma nogein

Tidur di sini

Berdasarkan contoh-contoh di atas, dengan jelas dapat dilihat bahwa kelima 
kalimat di atas adalah kalimat perintah. Kalimat-kalimat tersebut membatasi ataupun mengatur tingkah laku seseorang. Contoh 1) dan 2) merupakan kalimat yang membatasi tingkah laku seseorang, dalam konteks ini; tindakan yang akan diambil. Kemudian, contoh 3) sampai 5) merupakan tata bahasa yang memberikan perintah untuk mengatur perilaku seseorang dalam bertindak. Contoh-contoh di atas merupakan bukti bahwa bahasa Hubula dapat digunakan untuk mengatur perilaku seseorang. Dengan demikian, fungsi regulatoris terdapat dalam bahasa Hubula.

\section{PENUTUP}

Berdasarkan hasil penelitian terhadap bahasa suku Hubula, dapat disimpulkan bahwa bahasa ini memiliki struktur kalimat dapat dipahami dengan mudah. Walaupun memiliki 24 pola kalimat, tetapi ada satu standar pola yang menjadi pola utama untuk pembelajaran dan penggunaan bahasa ini. Perbendaharaan kata yang belum ada akan diserap dari bahasa Indonesia yang mendukung penggunaan bahasa Hubula dalam perkembangan zaman. Ditinjau dari segi fungsi, bahasa ini memiliki beberapa fungsi primer. Fungsi-fungsi bahasa dalam bahasa suku Hubula, antara lain (1) fungsi personal, (2) fungsi informatif, (3) fungsi interaksi, (4) fungsi regulatoris. Namun, penelitian ini masih belum sempurna dan perlu kajian kebahasaan dengan memperhatikan lebih dalam lagi tentang struktur bahasa Hubula.

\section{DAFTAR PUSTAKA}

Chaer, Abdul. 2007. Linguistik Umum Cetakan Ketiga. Jakarta: Rineka Cipta.

Itlay, Simeon. 1994. Kebudayaan Jayawijaya Dalam Pembangunan Bangsa. Jakarta: Pustaka Sinar Harapan.

Matthiessen, Peter, 1987. Under The Mountail W all. United State of America: Paperback.

Rokhma, Fathur. 2013. Sosiolinguistik; Suatu Pendekatan Pembelajaran Bahasa Dalam Masyarakat Multikultural. Jakarta: Graha Ilmu.

Samapra, Keraf. 2005. Smarapradhipa. Jakarta: Balai Pustaka.

Samsuri, 1982. Analisis Bahasa. Jakarta: Erlangga.

Samakori, Habel. 2008. Pemetaan Suku-Suku di Tanah Papua. Jayapura: Dinas Kebudayaan Pemerintah Provinsi Papua.

Sutopo. H.B. 2002. Metode Penelitian Kualitatif Teori dan Aplikasinya dalam Penelitian. Surakarta: Sebelas Maret University Press.

Tarigan, Henry Guntur. 1986. Pengajaran Pragmatik. Bandung: Angkasa.

UUD 1945 Pasal 32 ayat 2 dan pasal 36 Bab XV.

Wardhaugh, Ronald. 1992. Introduction to Sociolinguistics (Fifth Edition). Victoria, Australia: Blackwell Publishing.

Wetipo, Alpius. 2018. Suku Hubula Budaya Perang Suku Masa Lalu. Wamena: Dinas Kebudayaan dan Pariwisata Kabupaten Jayawijaya.

Wetipo, Alpius. 2018. Kamus Praktis Percakapan Bahasa Daerah (Suku Hubula).Wamena: Dinas Kebudayaan dan Pariwisata Kabupaten Jayawijaya.

Wibowo, Wahyu. 2001. Manajemen Bahasa. Jakarta: Gramedia Pustaka Utama. 